\title{
O tych, którzy w czas wyjechali. Wywiad z Bernardo Kucinskim
}

Aleksandra Pluta

TEKSTY DRUGIE 2018, NR 5, S. 405-414

DOI: $10.18318 /$ td.2018.5.24

B ernardo Kucinski urodził się w 1937 roku w São Paulo. Jego ojciec, Majer Kuczyński, urodzony w 1904 roku we Włocławku, wyemigrował do Brazylii jeszcze przed wybuchem II wojny światowej, na fali rosnącego antysemityzmu, w 1935 roku. Matka Bernarda, Estera z domu Majerczak, dołączyła do męża niecały rok później. Bernardo Kucinski jest dziennikarzem, pisarzem, emerytowanym profesorem Uniwersytetu w São Paulo, USP. W czasie dyktatury wojskowej w Brazylii Kucinski był opozycyjnym działaczem politycznym, za co został skazany. W latach 1971-1974 przebywał w Londynie, gdzie pracował dla BBC.W 1991 roku obronił doktorat na temat prasy alternatywnej w Brazylii w latach dyktatury. Był doradcą do spraw komunikacji społecznej byłego prezydenta Luíza Inácia Luli da Silvy podczas jego pierwszej kadencji. W 1997 roku został laureatem brazylijskiej nagrody literackiej Jabuti za książkę Jornalismo econômico. Jego książka $K$ - relato de uma busca znalazła się w finale nagród literackich São Paulo de Literatura oraz Portugal Telecom w 2012 roku. Kucinski jest ponadto autorem
Bernardo Kucinski

- urodził się W 1937 roku w São Paulo.

Dziennikarz, pisarz, emerytowany profesor Uniwersytetu w São Paulo, USP. Autor wielu książek, m.in. $K$ - relato de uma busca, Você vai voltar pra mime outros contos.

Aleksandra Pluta - doktorantka w Instytucie Teorii Literatury Universidade de Brasília. Magister dziennikarstwa na Università La Sapienza w Rzymie. Autorka książek na temat polskiej imigracji w krajach Ameryki Łacińskiej. 
wielu książek, m.in. Vocêvai voltar pra mime outros contos, Jornalistas e Revolucionários, Cartas ácidas da Campanha do Lula.

Aleksandra Pluta: Pamiętam, że po raz pierwszy zobaczyłam Pana książki w jednej z księgarni w São Paulo. Od razu zwróciłam uwagę na polskie nazwisko na okładce i to właśnie wzbudziło moje zainteresowanie. Kiedy jednak poprosiłam Pana o wywiad, podkreślił Pan, żebym najpierw przeczytała książkę Pana ojca,Imigrantes, Mascates e Doutores. Z jej lektury dowiedziałam się, że jest Pan synem żydowskiego emigranta, który urodził się we Włocławku. Czy mógłby Pan opowiedzieć historię ojca i jego emigracji?

Bernardo Kucinski: Mój ojciec, Majer Kuczyński, urodził się w 1904 roku we Włocławku. Opowiadał mi, że był tak biedny, że jadł jajko tylko raz w roku, w dniu swoich urodzin. Zawsze myślałem, że przesadzał, ale później odkryłem jakieś jego zapiski, w których rzeczywiście to potwierdza. Było ich dziesięcioro rodzeństwa, w dniu urodzin każdy dostawał w prezencie jajko. Tak więc naprawdę byli oni bardzo biedni. To jest jedna z historii, którą ojciec często opowiadał. Lubił też wspominać, że jako młody chłopak został aresztowany za to, że brał udział w tworzeniu lewicowej syjonistycznej partii politycznej, $\mathbf{Z} y-$ dowskiej Socjaldemokratycznej Partii Robotniczej „Poalej Syjon”. Grupka, do której należał, wyłamała się z tej partii, by utworzyć jeszcze bardziej lewicowe ugrupowanie - „Poalej Syjon - Lewica”. To była radykalna, marksistowska mniejszość tworząca odrębną partię. Mój ojciec był ijdyszystą i syjonistą. Został aresztowany i wsadzony do więzienia, gdzie dzielił celę z tzw. „Królem złodziei". Wspominał też sytuację, jak to jego matka zaniosła mu któregoś dnia do więzienia tradycyjne potrawy z okazji Pesach, a on, ponieważ był młodzieńcem, który odrzucał religię i wszystkie jej rytuały, odmówił przyjęcia jedzenia.Został za to pobity w celi przez swych współwięźniów. Proszę sobie wyobrazić, co mogła oznaczać dla innych odmowa jedzenia w tak skrajnych warunkach. Opowiadał również, że po wyjściu z więzienia pewnego dnia poszedł do banku opłacić rachunki swego ojca i został napadnięty - zrabowali mu pieniądze i dokumenty. Udał się wtedy do swego starego znajomego z celi, „Króla złodziei”, który już się o to postarał, żeby mu te pieniądze oddano.Tego rodzaju zabawne historyjki opowiadał mi mój ojciec.

1 Żydowska Socjaldemokratyczna Partia Robotnicza "Poalej Syjon" (z hebr. פועלי ציון Robotnicy Syjonu; jid. Jidisze Socjalistisz-Demokratisze Arbeter Partaj "Poalej Cion”) - żydowska partia socjalistyczno-syjonistyczna działająca w Polsce w latach 1906-1950. 


\section{Pana ojciec wyemigrował do Brazylii jeszcze przed wybuchem II wojny światowej?}

Tak, w 1935 roku. Udało mu się opuścić Polskę, zanim nastąpiło najgorsze. Natomiast rodzina mojej matki, która również mieszkała w Polsce, została zamordowana przez nazistów, w przeciwieństwie do rodziny mojego ojca, którego niemalże wszyscy bracia wyemigrowali do Brazylii, z wyjątkiem najmłodszego, który umarł jeszcze w Polsce w wyniku rany na stopie, której się nabawił, grając w piłkę, i którą ukrywał przed rodziną. Żydzi w Polsce byli raczej religijni, a uprawianie sportu nie było dla nich czymś typowym. Właśnie dlatego ukrył tę ranę przed rodzicami i umarł, ponieważ wdała mu się tam jakaś poważna infekcja.Zmarły jeszcze dwie siostry mego ojca: jedna, która wraz z nim była więziona za swoją działalność polityczną, zachorowała w więzieniu na gruźlicę i umarła jeszcze przed wojną. Druga została zamordowana przez nazistów we Francji. Oprócz ich trzech, spośród dziesięciorga rodzeństwa, wszyscy wyemigrowali do Brazylii. Z kolei ze strony mojej matki, cała jej rodzina została zamordowana przez nazistów z wyjątkiem jednej kuzynki, która wyjechała do Izraela, i wujka Benka, który walczył w AK, a potem także wyjechał do Izraela, gdzie niedawno zmarł. Oprócz tych dwóch osób wszyscy zostali zamordowani: rodzina, przyjaciele... Ale o tym moi rodzice nie mówili. To nie był temat do rozmów. Na temat inwazji Niemców ani na temat Holocaustu ojciec nigdy nic nie mówił, ale jest to zjawisko znane wśród rodzin, które przeżyły Zagładę. Nie przekazywano tego dzieciom. Pomijano ten temat ciszą. Czasami, wiele lat później, coś pewnie mógł na ten temat powiedzieć, ale na ogół temat był ten pomijany.

Tak jak mówiłem, tata opowiadał o Polsce tylko zabawne historyjki. Być może nawet dlatego, by nieco rozchmurzyć własne wspomnienia. Z kolei mój wujek Benek, brat mojej matki, którego spotkałem kilka razy w Izraelu, więcej opowiadał o Włocławku, o domu, w którym mieszkał. Rodzina mojej matki nie była tak biedna, jak rodzina mego ojca. Oni mieli sklepik spożywczy i mój ojciec chodził tam podkradać jakieś słodycze. Wujek Benek twierdził, że to z powodu tych słodyczy ojciec ożenił się z moją matką.

I oczywiście nasze miasto - Włocławek. To co jest niezwykłe, to wielkie bogactwo życia kulturalnego wśród Żydów przed wojną. Ile tam było stowarzyszeń literackich, politycznych, ile szkół! Przeogromne bogactwo życia kulturalnego. To, co się stało w czasie wojny, to była katastrofa kulturalna, bo to nie tylko chodzi o to, że zabili jakiegoś Żyda czy jakiegoś rabina... Zabite zostało całe to przebogate życie kulturalne, którym tętniło miasto. 
Pana ojciec pisał przede wszystkim opowiadania. Pisał w języku jidysz, a na język portugalski przełożyły je jego brazylijskie uczennice, ponieważ Pana ojciec był w São Paulo nauczycielem języka jidysz. Czy jego literacki talent obudził się w nim jeszcze w młodzieńczych latach w Polsce?

Mój dziadek, ojciec mojego ojca, był szewcem i rabinem. Jak mówiłem, byli bardzo biedni. Dzieci jadły rękoma, tylko dorośli mieli sztućce. Jego matka pochodziła z bardzo biednej rodziny, ale ponieważ umiała bardzo dobrze gotować, pracowała jako pomoc domowa u bogatej rodziny. Jako że młode panny z domu, w którym pracowała, chciały się od niej nauczyć przyrządzać tak wyśmienite potrawy, matka mojego ojca umówiła się z nimi, że ona nauczy je gotować, w zamian za co one nauczą ją czytać i pisać. Nauczyła się zatem pisać i czytać. I ile ona czytała! To ona przekazała memu ojcu miłość do literatury. Należy tu jednak nadmienić, że mój ojciec należał do pokolenia, które zbuntowało się przeciwko religii. Jego tożsamość żydowska nie znajdowała się w religii, lecz w kulturze. Przede wszystkim w kulturze i literaturze jidysz. Ojciec stał się fanatykiem literatury jidysz. Miał talent literacki już od najmłodszych lat. Zaczął pisać różne historie w wieku dwunastu, trzynastu lat. Pisał dla gazetki szkolnej i dla lokalnych gazet. Jego bracia uznali, że miał talent i zbierali dla niego pieniądze, żeby mógł kontynuować naukę w gimnazjum. Był jedynym spośród braci, który kontynuował naukę, ponieważ jego rodzeństwo dostrzegło w nim talent literacki i powołanie. Już w młodości zaangażował się zarówno w twórczość literacką, jak i w działalność polityczną. Miał w sobie wrodzony talent działacza politycznego i zdolności przywódcze, poszło za nim wielu ludzi. Brał udział również w tworzeniu YIVO - Żydowskiego Instytutu Naukowego, ośrodka w jego mieście. To bardzo ważny projekt, którego celem było studiowanie kultury jidysz. Ojciec brał udział we wszystkich tych działaniach, zarówno politycznych, jak i kulturalnych. Z tego też powodu dwa razy został aresztowany. Jeden raz znajomi zrzucili się na łapówkę, dzięki której wypuszczono go z więzienia. Ojciec nie tylko nie był religijny, ale był także antyklerykalny, walczył przeciwko religii. On się jej przeciwstawiał, a nie tylko nie akceptował. Do końca swego życia nie lubił rabinów. Prowokował, jadał wieprzowinę. Ale gdy się tak zastanowię, to muszę przyznać, że u nas w domu w Brazylii nigdy nie jadło się feijoady². Można zatem pojmować

2 Feijoada (port.) - narodowa potrawa z czarnej fasoli z dodatkiem różnych mięs, zwłaszcza wieprzowiny. 
jedzenie jako rytuał religijny albo zwyczaj kulturowy. Dla nas mogło mieć ono znaczenie tylko kulturowe, nie religijne. Bo pamiętam, że matka od czasu do czasu kupowała jakieś wędliny.

\section{W jakich okolicznościach Pana ojciec wyemigrował do Brazylii?}

Mój ojciec, zanim wyjechał do Brazylii, przez rok mieszkał w Berlinie. Wielu jego braci również przebywało tam przez jakiś czas. Berlin był dla nich innym światem. Moja ciotka, siostra mego ojca, zachwycała się, że kobiety, Żydówki, mogły tam jeździć na rowerze, co było nie do pomyślenia w ich rodzinnym Włocławku. W Berlinie mój ojciec nadal zajmował się polityką, napisał też z jakimś znajomym artykuł na temat życia Żydów w Niemczech. Taki był z niego typ - wieczny działacz polityczny. Kiedy trafił do Brazylii stwierdził, że nie ma tu żydowskiej klasy robotniczej. On wywodził się jednak z czasów i z miejsca, gdzie prawie wszyscy, a przynajmniej znaczna część rzemieślników, wyrobników czy robotników, to byli Żydzi. Największym związkiem robotniczym był Bund, a mój ojciec wywodził się właśnie z tego środowiska. Kiedy trafił do Brazylii, wszyscy Żydzi zajmowali się handlem, mieli sklepiki, sprzedawali na raty. Właśnie dlatego przestał zajmować się polityką. Może też dlatego, że był nią już zmęczony, ale głównie ponieważ nie widział tam żydowskiej klasy robotniczej.

\section{Czym zajmował się Pana ojciec po przyjeździe do Brazylii?}

Rzucił politykę i zaczął zajmować się tylko kulturą. Pomógł założyć Colégio Hebraico, uczył języka jidysz, przekazywał kulturę jidysz, kształcił przyszłych tłumaczy. Poświęcał się jidysz. Pisał też opowiadania. Brazylia była dla niego odkryciem. To była dla niego nowa diaspora. W każdym miejscu, gdzie mieszkają Żydzi, jest inny rodzaj diaspory będący mieszanką kultury żydowskiej z kulturą lokalną. Kiedy Żydzi przyjeżdżali do Brazylii tworzyli swoje własne stowarzyszenia, np. Żydów z Besarabii czy Żydów z Litwy. Mój ojciec znalazł dla siebie miejsce w stowarzyszeniu Żydów z Besarabii.

W książce Imigrantes, Mascates e Doutores opisuje on jednak doświadczenie obwoźnego sprzedawcy na peryferiach miasta São Paulo. Czy opowiadania zawarte w tej książce są fikcją, czy może oparte są na jego własnym doświadczeniu? 
Dzięki jego wrażliwości i duszy pisarza, zachwycał się odkryciem Brazylii, zaczął pisać o różnych osobach, które spotykał w pracy. A spotykał ich wiele, ponieważ po przyjeździe zaczął pracować jako sprzedawca, choć w rzeczywistości najbardziej interesowały go historie, których wysłuchiwał od napotkanych ludzi. To one były dla niego bardziej ciekawe niż samo sprzedawanie.To, co opisał w książce, to jego własne doświadczenie. Najpierw miał wózeczek, z którym jeździł od domu do domu, później otworzył sklepik, ale przesiadywał zawsze gdzieś ukryty głęboko w kącie, pisząc, zawsze miał w sobie ten pisarski talent. Angażował się też czasem w pewne polemiki o charakterze politycznym, ale nie tak często jak w Polsce. W São Paulo to zazwyczaj on przygotowywał przemówienia z okazji obchodów rocznicy wybuchu powstania w getcie czy w dniu niepodległości Izraela. Był wielkim mówcą. Mówił tak dobrze i z taką pasją w jidysz, że nawet osoby, które nie znały języka, twierdziły, że rozumiały, co mówi. I jego lekcje też były takie. Często był zapraszany, by przemawiać. Stał się niemalże oficjalnym mówcą we wspólnocie. I ciągle pisał. Jak wspomniałem, jeszcze w Polsce pisał dla dwóch polskich gazet, które publikowały w jidysz, potem pisał także dla gazet w jidysz publikowanych w Nowym Jorku, Buenos Aires i São Paulo. Były to przede wszystkim krótkie historie i opowiadania.

\section{Jak to się stało, że Pana ojciec wybrał za swój cel Brazylię?}

Mój ojciec przybył tu sam, na zaproszenie jakiegoś kuzyna, a matka ze starszym bratem, który był wówczas bobasem, dołączyła do ojca niecały rok później. Wydaje mi się, że intencją ojca była emigracja do Stanów Zjednoczonych, ale z jakiegoś powodu, którego nie znam, trafił do Brazylii. Istnieje wiele historii emigrantów, którzy mylili Amerykę Północną z Południową, Stany Zjednoczone z Argentyną czy Brazylią itp. Historie emigrantów, którzy wysiedli ze statku w porcie w Recife i nie zdążyli wsiąść do niego z powrotem w drodze do Rio de Janeiro, Santos czy Buenos Aires, i zostawali już na stałe w Recife, też są powszechnie znane. Nawet ja napisałem kiedyś kilka opowiadań na ten temat. Są też historie o Żydach, którzy emigrowali do Boliwii, ponieważ przez pewien czas tylko Boliwia przyjmowała Żydów. Takie są te historie emigrantów.

\section{Jak emigracja wpłynęła na życie Pana rodziny?}

Kiedy żydowska rodzina z Polski przybywała do Brazylii w tamtym czasie, radykalnie zmieniał się model rodziny. To już nie była rodzina 
z dziesięciorgiem dzieci, jak było w Polsce, tylko z dwojgiem lub trojgiem. To typowe dla emigrantów, nie tylko żydowskich, ale również włoskich czy hiszpańskich. Jest to poważna zmiana w strukturze rodziny. Jak wyglądała ta emigracja? Najpierw przyjeżdża wujek. Zaprasza drugiego. Potem tych dwóch zaprasza trzeciego. Potem ci trzej zapraszają czwartego itd. Aż w końcu przywożą rodziców i dziadków. Dziadkowie zaczynają mieszkać w bardzo skromnym miejscu, które wynajmują dla nich ich dzieci, bracia mieszkają każdy w innym miejscu, rodziny spotykają się dwa razy do roku, z okazji Pesach i Nowego Roku. Powoli zaczynają spotykać się coraz rzadziej. Najpierw jeszcze na ślubach i pogrzebach, potem już tylko na pogrzebach. I cała ta wielka rodzina się rozłazi. Emigracja to nie tylko zmiana w położeniu geograficznym. Emigracja może też oznaczać kres pewnego modelu rodziny, rodziny patriarchalnej, której głową był najstarszy mężczyzna, czy to szewc, czy rabin, wokół którego kręciły się dzieci. Taki obrazek zanika. Taki model rodziny przestaje istnieć. W naszym przypadku było jeszcze gorzej, ponieważ nasza rodzina mieszkała w dzielnicy odległej od centrum, na północnym skraju São Paulo, w dzielnicy Cantareira. Ojciec wychodził rano ze swoim wózeczkiem sprzedawać towar, a ja zostawałem na ulicy z innymi dzieciakami. Jeden był synem włoskich emigrantów, inny - hiszpańskich. Więc w zasadzie nie mieliśmy takiego rodzinnego życia, z mamą, tatą, dziećmi, żydowskimi tradycjami. Mój brat, który urodził się jeszcze w Polsce, był wielkim buntownikiem, uciekał z domu, różnica wieku między nami była bardzo duża. Mieliśmy takie fragmentaryczne życie rodzinne. Może też dlatego nie było okazji, by ojciec przekazał nam jakieś wspomnienia z Polski. Bardzo mało rozmawialiśmy. Jeśli chodzi o warunki bytowe, to z pewnością z dnia na dzień się polepszały, szczególne jeśli pomyśli się o biedzie, którą mój ojciec znał z Polski. Polepszyły się po pierwsze dlatego, że ojciec był znany w tutejszym środowisku żydowskim, wśród ludzi, którzy osiedlili się tu wcześniej, mieli tu swoje warsztaty, interesy, sklepy. Imigranci, nie tylko w Brazylii, tworzą własne dzielnice, własne sektory, własne branże: np. Portugalczycy zakładają piekarnie, Żydzi zajmują się konfekcją. Prawie wszystkie sklepiki z odzieżą należały do Żydów. Imigrant szedł więc do dzielnicy Bom Retiro w São Paulo, otrzymywał na kredyt kilkanaście koszul czy swetrów i zaczynał je sprzedawać po domach. Mój ojciec nie miał problemu, by otrzymać towar na kredyt, ponieważ pochodził z szanowanej rodziny. Biednej, ale szanowanej. Po przyjeździe zaczął więc sprzedawać. Odznaczał się szczególną empatią wobec stałych klientów, słuchał ich historii. Może też dzięki temu szybko udało mu się wybić finansowo. Kiedy miałem siedem lat, otworzył ze wspólnikiem sklep w dzielnicy 
Tucuruvi i nie musiał już dłużej sprzedawać jako obwoźny handlarz. I tak powoli szło coraz lepiej. Najpierw wynajmowali sklep, później mieli już swój własny, to był znaczny postęp. Spora część żydowskich imigrantów w Brazylii w tamtych czasach przeszła podobną drogę. Szybko się dorabiali.

\section{Czy mógłby Pan na przylłładzie swojej rodziny spróbować nieco uogólnić} i opowiedzieć, jak wyglądała typowa emigracja polskiego Żyda do Brazylii? Czy nowe życie wpłynęło na rozluźnienie relacji we wspólnocie i na zmniejszenie roli religii w życiu?

Żyd z Polski, który trafiał do São Paulo, zazwyczaj zamieszkiwał na początku w jakiejś dzielnicy na peryferiach miasta, ponieważ wynajem tam był tańszy niż w centrum. W takich dzielnicach nie było sklepów, z wyjątkiem nielicznych sklepików prowadzonych zazwyczaj przez Portugalczyków. Dawało się więc takiemu Żydowi szansę na to, by mógł handlować towarem, chodząc od domu do domu. Nie mógłby tego robić w centrum miasta, bo tam było dużo sklepów. Większość Żydów zamieszkiwała więc peryferie miasta, co utrudniało kontynuowanie typowo żydowskiego trybu życia, które znali jeszcze z Polski. Dostosowywali się więc do nowych warunków. Raz na tydzień lub raz na miesiąc jeździli do dzielnicy Bom Retiro, kupowali jakieś typowe żydowskie przysmaki, a religijne życie żydowskie miało szansę przetrwać tylko w nielicznych dzielnicach: jedna synagoga znajdowała się w dzielnicy Ipiranga, inna w dzielnicy Brás, ale tam, gdzie ja mieszkałem, nie było ani jednej.

Żydzi z Bom Retiro przybyli jako pierwsi. Jeszcze przed tym, jak do Brazylii trafił mój ojciec. Jak już wspomniałem, mieli tam swoje warsztaty, swoje sklepiki. Byli już dobrze ustawieni. Może i sprzedawali na raty swoje produkty, ale sprzedawali je bezpośrednio ze swoich sklepików, a nie jako obwoźni sprzedawcy, którzy, rzecz jasna, w hierarchii stali niżej od sklepikarzy. Szyli ubrania. Sprzedawali je raczej hurtowo, nie detalicznie. I to właśnie ci Żydzi z Bom Retiro prowadzili jeszcze żydowskie życie. Była tam synagoga, i to nie jedna, była szkoła żydowska. Był tam też placyk, który w soboty wypełniał się ludźmi, gadaniną i plotkami. Tam, gdzie my mieszkaliśmy, nie było tego. Na mojej ulicy nasza rodzina była jedyną żydowską rodziną. Jacyś inni Żydzi mieszkali gdzieś tam daleko, o jakieś dziesięć przecznic dalej. Między polskimi imigrantami a Żydami z Polski w Brazylii nie było kontaktu. Ja chodziłem do gimnazjum żydowskiego, które pomagał założyć mój ojciec. Autobusem 
jeździłem z mojej dzielnicy do dzielnicy Bom Retiro. Tam odźwiernym był Polak - to był jedyny Polak, którego znałem w tamtych czasach.

Mówi Pan wiele o utracie tradycji żydowskich. Jednak nie da się ukryć, że dziś w São Paulo środowisko żydowskie jest bardzo liczne i wydaje się silne.

Religijni Żydzi to zjawisko dość świeże tu w São Paulo. Ponieważ większość Żydów, którzy osiedlili się w Brazylii, po przyjeździe tutaj przestawała być religijna. Dziś pójdziesz do dzielnicy Higienópolis w São Paulo, a tam na ulicach widać samych religijnych Żydów. To jest coś nowego, tego wcześniej nie było. Kiedyś nie chciano demonstrować żydowskich cech, jak broda czy pejsy, nie nosiło się jarmułek, długich płaszczy czy kapeluszy. Dziś można to zobaczyć, kiedyś tego się nie widziało. Proszę zwrócić uwagę na nasze imiona: ja, Bernardo, moja siostra, Anna - to nie są typowe imiona żydowskie, jak Abraham, Izaak czy Jacob. Są to imiona, które w pewien sposób nas chronią. Może zostały nam nadane z powodu obawy przed nazizmem albo dlatego, że mój ojciec odrzucał religię. Nie jestem tego pewien.

\section{A Pańska twórczość literacka? Czy uważa się Pan w pewien sposób za kontynuatora pracy twórczej ojca?}

Byłem dziennikarzem przez ponad trzydzieści lat i nigdy nie pisałem fikcji. Pracowałem też na Uniwersytecie w São Paulo. Kiedy przeszedłem na emeryturę, ogarnęło mnie poczucie pustki. Wtedy właśnie zacząłem pisać i zagłębiać się w historię mojej rodziny. Tak właśnie powstała moja książka $K$ - relato de uma busca. Zależałoby mi bardzo, by została ona przetłumaczona na język polski i opublikowana w kraju moich rodziców. 


\section{Abstract}

\section{Aleksandra Pluta}

UNIVERSIDADE DE BRASÍLIA

Those Who Left in Time: An Interview with Bernardo Kucinski

Pluta interviews Bernardo Kucinski, the acclaimed Brazilian writer whose novel $K$ thematizes his Polish-Jewish heritage. Several novels by Kucinski have appeared in English, German, French, Spanish, and Catalan, but none of them have been translated into Polish. In this interview Kucinski focuses on the biography of his father, the writer Meier (Majer) Kucinski, his experience as an émigré and his relationship to Judaism.

\section{Keywords:}

emigration, literature, Polish Jews, Judaism, Brazil 